\title{
CONSISTENCY AND COHERENCE IN ADJUDICATING THE ECB'S UNCONVENTIONAL MONETARY POLICY
}

\author{
Carsten Gerner-Beuerle* (iD And Esin KüçüK†
}

\begin{abstract}
Few court cases in the history of European integration have been more controversial than the decisions of the Court of Justice of the EU and the German Federal Constitutional Court on the European Central Bank's public sector asset purchase programmes. This article regards consistency and coherence in the case law as uncontroversial minimum conditions that have to be satisfied for the decisions to gain legitimacy. It assesses the case law against this benchmark and determines the limits of asset purchase programmes under a consistent and coherent application of the legal tests developed by the courts.
\end{abstract}

Keywords: EU law, Gauweiler, Weiss, monetary policy, monetary financing, asset purchase programmes, proportionality.

\section{INTRODUCTION}

At the heart of the EU's response to the unprecedented challenges that European monetary union has faced since the sovereign debt crisis are several unconventional monetary policy measures of the European Central Bank (ECB) that involve the large-scale purchase of government bonds of Eurozone Member States. At the height of the sovereign debt crisis in 2012, the ECB adopted a decision on so-called outright monetary transactions (OMT). The OMT decision consisted in an announcement that the Eurosystem (the ECB and the euro area national central banks) stood ready to buy potentially unlimited amounts of government bonds of Member States that were in receipt of financial assistance from the European Financial Stability Facility (EFSF) or its successor, the European Stability Mechanism (ESM), in the secondary markets. ${ }^{1}$ Under a second programme, the public sector asset purchase programme (PSPP), also known as 'quantitative easing', the

* Professor of Commercial Law, University College London, c.gerner@ucl.ac.uk.

$\dagger$ Lecturer in Law, Lancaster University, e.kucuk@lancaster.ac.uk. We are grateful to Joxerramon Bengoetxea, Damian Chalmers, Oliver Gerstenberg, Matthias Lehmann, Bernhard Ludwig, the participants of a workshop at the London School of Economics, two anonymous reviewers and the editors of the International \& Comparative Law Quarterly for helpful comments and suggestions. All remaining errors are ours.

1 ECB Press Release, Technical features of Outright Monetary Transactions, 6 September 2012. 
Eurosystem purchases government bonds of all Member States in order to enhance the transmission of monetary policy and contribute to a return of inflation rates to the ECB's target of close to 2 per cent. ${ }^{2}$ Most recently, in 2020, the ECB adopted a pandemic emergency purchase programme (PEPP) in response to the risks to price stability posed by the COVID-19 pandemic. ${ }^{3}$

Opinions about the ECB's asset purchase programmes differ sharply. Central bank asset purchases have unequal effects on income and wealth distribution depending on prevailing economic conditions in the countries or regions where they take place. The purchase of government bonds from financial institutions improves the institutions' liquidity and encourages lending, thus resulting in a downward pressure on interest rates. ${ }^{4}$ This favours borrowers and disadvantages savers, to give one example that has featured prominently in public debate. Given that the savings rate differs substantially across countries in the Eurozone, ${ }^{5}$ it is unsurprising that OMT and the PSPP have been heavily criticised in some countries, while they have been welcomed in others. ${ }^{6}$

The legal assessment of public sector asset purchases, likewise, is highly contentious. Both OMT and the PSPP were challenged before the German Federal Constitutional Court (FCC). The FCC referred both cases to the Court of Justice in its first two, and so far, only, preliminary references under Article 267 of the Treaty on the Functioning of the EU (TFEU). ${ }^{7}$ The Court of Justice confirmed the legality of OMT in Gauweiler ${ }^{8}$ and of the PSPP in Weiss. ${ }^{9}$ When the cases returned to the FCC, the Constitutional Court expressed deep reservations. It ultimately accepted Gauweiler, but not without emphasising that it met 'with serious objections'. ${ }^{10}$ In Weiss, the FCC went a step further and denied the decision of the Court of Justice binding force in

2 Decision (EU) 2015/774 of the ECB on a secondary markets public sector asset purchase programme (ECB/2015/10), recast as Decision (EU) 2020/188 (ECB/2020/9).

3 Decision (EU) $2020 / 440$ of the ECB on a temporary pandemic emergency purchase programme (ECB/2020/17), amended most recently by Decision (EU) 2021/174 (ECB/2021/6), which enlarged the overall envelop of the programme to $€ 1,850 \mathrm{bn}$.

${ }^{4}$ The effects of asset purchases will be discussed in more detail in Section III.A below.

${ }^{5}$ MH Stierle and S Rocher, 'Household Saving Rates in the EU: Why Do They Differ So Much?' (European Economy Discussion Paper 005, European Commission, Directorate-General for Economic and Financial Affairs 2015).

${ }^{6}$ The criticism in some Member States was strident, including, for example, the claim that savers were 'expropriated'. For a critical assessment and refutation of this and other claims, see I Schnabel, 'Narratives about the ECB's Monetary Policy - Reality or Fiction?' (speech at the Juristische Studiengesellschaft, Karslruhe, Germany, 11 February 2020) <https://www.ecb. europa.eu/press/html/index.en.html $>$.

7 BVerfGE 134, 366, 2 BvR 2728/13 (OMT referral); BVerfGE 146, 216, 2 BvR 859/15 (PSPP

referral). $\quad{ }^{8}$ Case C-62/14 Gauweiler and Others v Deutscher Bundestag EU:C:2015:400.

9 Case C-493/17 Weiss and Others EU:C:2018:1000. A third important judgment on monetary union, Case C-370/12 Thomas Pringle v Ireland EU:C:2012:756, concerned the European Stability Mechanism and is thus not the focus of this article. However, in Pringle, the Court of Justice developed several of the legal principles that were applied in Gauweiler and Weiss, and we will refer to the decision where necessary.

${ }^{10}$ BVerfGE 142, 123, 2 BvR 2728/13 (FCC judgment on OMT) para 181. 
Germany, ${ }^{11}$ arguing that the Court's reasoning was 'simply not comprehensible', ${ }^{12}$ 'objectively arbitrary'13 and 'no longer tenable from a methodological perspective'. ${ }^{14}$ The literature is more sympathetic, but there is no common view on either the merits of the arguments advanced by the two courts, or on the conditions under which asset purchases are in compliance with the monetary policy mandate of the ECB and the prohibition of monetary financing enshrined in the Treaty. ${ }^{15}$

The disagreements have serious repercussions. In the short run, they cast doubt on the permissibility of the PEPP, which has been challenged as unconstitutional in the FCC. ${ }^{16}$ In the long run, the FCC's response to Gauweiler and Weiss undermines the supremacy of the EU legal order and the authority of the Court of Justice, even though the FCC's reasoning and its conclusion in Weiss that the Court of Justice acted ultra vires can be criticised on a variety of grounds. ${ }^{17}$ The Court of Justice will only be able to (re-)assert its authority as final arbiter of the legality of monetary policy decisions if the legal tests that it has developed withstand scrutiny. This is the topic of the present article. We assess the Court's case law against the benchmarks of consistency and coherence as preconditions for its ability to adjudicate with authority and legitimacy. Likewise, a consistent and coherent application of the legal principles underlying public sector asset purchases is indispensable for the ECB's unconventional monetary policy measures to gain acceptance across the Eurozone, including in those regions where they are perceived as having negative consequences for particular constituencies.

11 Bundesverfassungsgericht [German Federal Constitutional Court], judgment of 5 May 2020, 2 BvR 859/15 (FCC judgment on PSPP) para 163. In a decision of 29 April 2021, 2 BvR 1651/15, 2 BvR 2006/15, the FCC rejected two applications that sought to enforce the judgment of 5 May 2020 and enjoin the German Bundesbank from participating in the PSPP, holding that the ECB had taken steps to address the shortcomings of the PSPP decision that the FCC had identified in its judgment. In June 2021, the Commission nonetheless decided to initiate infringement proceedings against Germany on the ground that Germany had breached the principle of primacy of EU law, INFR (2021)2114, Memo INF_21_2743. $\quad{ }^{12}$ FCC judgment on PSPP (n 11) para 118.13 ibid.

14 ibid para 119.

15 TFEU arts 119, 123(1), 127. For critical voices from the literature, see M Dawson and A Bobić, 'Quantitative Easing at the Court of Justice - Doing Whatever It Takes to Save the Euro: Weiss and Others' (2019) 56 CMLRev 1005, 1040; A Hinarejos, 'Gauweiler and the Outright Monetary Transactions Programme: The Mandate of the European Central Bank and the Changing Nature of Economic and Monetary Union' (2015) 11 EuConst 563, 575; N Scicluna, 'Integration through the Disintegration of Law? The ECB and EU Constitutionalism in the Crisis' (2018) 25 Journal of European Public Policy 1874, 1881-3. An in-depth treatment of all stages of the development of the case law on monetary union can be found in several special issues of the German Law Journal: Pringle in vol 14(1) (2013); the preliminary reference of the FCC in Gauweiler in vol 15(2) (2014); the Gauweiler judgment of the Court of Justice in vol 16 (4) (2015); and most recently the FCC's judgment in Weiss in vol 21(5) (2020).

16 'AfD-Fraktion im Deutschen Bundestag, Boehringer: AfD-Fraktion hat Organklage gegen das EZB-Anleihekaufprogramm PEPP eingereicht' [AfD group in the German Federal Parliament files a complaint challenging the ECB bond purchase programme PEPP] (Alternative für Deutschland, press release of 28 August 2020) <https://afdbundestag.de/boehringer-afdfraktion-hat-organklage-gegen-das-ezb-anleihekaufprogramm-pepp-eingereicht/>.

17 See Section III.B. 
The article makes three contributions. First, it directs attention to criteria used by the Court of Justice to determine whether a measure falls within the scope of the ECB's monetary policy mandate that have only been discussed in passing in the literature, if at all: the direct and indirect effects of a monetary policy measure. It shows that on an interpretation based on the ordinary meaning of these criteria the FCC's criticism that the ECB is able to define the scope of its mandate autonomously is misplaced, ${ }^{18}$ but also that Gauweiler and Weiss have been decided inconsistently by the Court of Justice.

Second, the article offers an analysis of the legality of the PEPP, and more generally of public sector asset purchase programmes, under a consistent and coherent application of the legal tests of the Court of Justice. It also shows that some of the criteria that are held out by the FCC as indispensable for public sector asset purchases to comply with the prohibition of monetary financing are incoherent. The article makes suggestions for how to align the tests of the two courts in order to alleviate the risk of further open judicial conflict when the proceedings over the legality of the PEPP reach the Court of Justice.

Finally, Gauweiler and Weiss are, arguably, 'hard cases', not only because of their political dimension, but also because the relevant Treaty provisions use terms that are neither defined in the Treaty, nor associated with a clearly delineated meaning, such as 'monetary policy'. ${ }^{19}$ In such cases, courts often appeal to legal principles of a higher order to resolve an interpretive conflict. ${ }^{20}$ However, higher-order principles, owing to their generality, will also often be open to different interpretations or, where two or more higherorder principles can be invoked, it may be difficult to reconcile these principles. ${ }^{21}$ For example, in the present context, there is a tension between the preservation of financial stability in the Eurozone, which may require fiscal transfers to address the asymmetric impacts of economic shocks on Member State finances, and budgetary autonomy of the Member States, which militates against transfer payments. ${ }^{22}$ While it is possible rationally to

18 It has been argued that democratic accountability of the ECB requires that the ECB cannot define its mandate autonomously, J de Haan and SCW Eijffinger, 'The Democratic Accountability of the European Central Bank: A Comment on Two Fairy-tales' (2000) 38 Journal of Common Market Studies 394, 397-8.

19 TFEU art 119(2).

20 The account of first and second-order conflicts in this paragraph draws on N MacCormick, 'The Limits of Rationality in Legal Reasoning' in N MacCormick and O Weinberger, $A n$ Institutional Theory of Law (Reidel 1986) 189, 203-5. MacCormick's conceptual framework has been applied to the legal reasoning of the Court of Justice by J Bengoetxea, The Legal Reasoning of the European Court of Justice (Clarendon Press 1993) 168-72, 224-5.

21 MacCormick (n 20) 203.

22 The Court of Justice, in Pringle (n 9) para 135, ascribed 'a higher objective, namely maintaining the financial stability of the monetary union' to art 125 TFEU. It accordingly held that 'the activation of financial assistance by means of a stability mechanism such as the ESM' was compatible with art 125 if it was 'indispensable for the safeguarding of the financial stability of the euro area as a whole', ibid para 136. On this aspect of Pringle, see K Tuori and K Tuori, The Eurozone Crisis: A Constitutional Analysis (Cambridge University Press 2014) 120-36, who speak of the 'two-order telos' of art 125. The FCC, on the other hand, in its OMT referral to the Court of 
disagree about the most appropriate resolution of a conflict over the interpretation of a principle, or between two principles, it can be assumed that there is broad agreement that any solution must be consistent and coherent. The approach proposed in this article can thus hope to establish common ground, on which further discussions can build.

The analysis that follows will be premised on the courts' understanding of the objectives of the relevant Treaty provisions and the legal tests developed by the courts. On that basis, the article will examine whether Gauweiler and Weiss have been decided consistently and coherently. Consistency, as the term is used here, refers to the non-contradictory formulation and application of legal rules and principles. A norm should be given the same meaning across and within cases, with the consequence that cases that differ factually along a relevant dimension should be treated differently, and cases that do not differ along that dimension should be treated alike, all else being equal. ${ }^{23} \mathrm{~A}$ legal solution to a particular social conflict is coherent if the rules that apply to the conflict contribute to the attainment of the higher-order principle that guides a regulation of the relevant issues. ${ }^{24}$ For example, if the preservation of sound public finances is seen as the main objective of the prohibition of monetary financing (as it is in the opinion of the Court of Justice), an interpretation that requires unconventional monetary policy measures to exhibit certain technical features is incoherent if these features do not in fact contribute to the preservation of sound public finances.

The article proceeds as follows. Section II gives a brief overview of the questions at issue in Gauweiler and Weiss. Sections III and IV form the core of the article. Through the lens of consistency and coherence, we first analyse the reasons given by the Court of Justice for holding that OMT and the PSPP fall within the monetary policy mandate of the ECB, and the reasons given by the FCC why the PSPP (but not OMT) exceeds the ECB's mandate. We then examine whether the view that the two asset purchase programmes do not constitute monetary financing (on which both courts agree) is coherent, given the objective of the prohibition of monetary financing. Section V determines the limits of public sector asset purchase programmes under a consistent and coherent application of the legal tests and analyses the legality of the PEPP. Section VI concludes.

\section{BACKGROUND}

The proceedings in Gauweiler and Weiss revolved around two foundational features of the constitutional architecture of European monetary union: the

Justice (n 7) para 102, emphasised the importance of the German parliament's budgetary autonomy, which would be violated if the EU institutions "created a mechanism [amounting] to an assumption of liability for decisions of third parties which entail[ed] consequences that [were] difficult to calculate'.

${ }_{23}$ The definition of consistency adopted in this article is based loosely on N MacCormick, Legal Reasoning and Legal Theory (Oxford University Press 1994) $106 .{ }_{24}^{24}$ ibid 106-7, 152-7. 
competences of the ECB and the European System of Central Banks (ESCB) in the area of monetary policy ${ }^{25}$ and the prohibition of monetary financing. ${ }^{26}$ The proceedings have been described in detail in the literature, and there is no need to reproduce these accounts here. ${ }^{27}$ Instead, we will focus on the characteristics, operation, and economic relevance of the measures challenged in the two cases - the two decisions of the ECB announcing outright monetary transactions and public sector asset purchases - insofar as this is relevant to our critique of the legal reasoning of the Court of Justice and the FCC.

Outright monetary transactions involve the purchase of government bonds of selected Member States in the secondary market with the aim of 'safeguarding an appropriate monetary policy transmission'. ${ }^{28}$ The Eurosystem's intervention is subject to no ex ante quantitative limits, but conditional on the participation of the Member States concerned in an EFSF or ESM macroeconomic adjustment programme that requires the implementation of macroeconomic reforms prepared and supervised by the European Commission in liaison with the ECB and IMF. ${ }^{29}$ Until today, the Eurosystem has carried out no transactions under its OMT programme.

The PSPP was adopted to respond to a 'materially increased ... downside risk to the medium-term outlook on price developments', which, in the words of the ECB, 'jeopardis[ed] the achievement of the ECB's primary objective of maintaining price stability'. ${ }^{30}$ Like OMT, the PSPP involves the purchase of government bonds in the secondary market. In contrast to OMT, the ECB and the euro area national central banks purchase the bonds of all Eurozone Member States largely in proportion to the ECB's capital key (with the exception of Member States whose bonds are not eligible for purchase ${ }^{31}$ ) and conditionality does not apply. ${ }^{32}$ The PSPP was initially carried out between March 2015 and December 2018 and restarted in November 2019. As of June 2021, cumulative net purchases (purchases minus redemptions) under the PSPP amounted to $€ 2.55 \mathrm{tn} .^{33}$

It is the stated aim of both OMT and the PSPP to address tensions in financial markets that, according to the ECB, were hampering the effective transmission

25 TFEU arts 119 and 127.

26 TFEU art 123(1).

27 From the voluminous literature, see on Gauweiler, among others: D Adamski, 'Economic Constitution of the Euro Area after the Gauweiler Preliminary Ruling' (2015) 52 CMLRev 1451; V Borger, 'Outright Monetary Transactions and the Stability Mandate of the ECB: Gauweiler' (2016) 53 CMLRev 139; Hinarejos (n 15); T Tridimas and N Xanthoulis, 'A Legal Analysis of the Gauweiler Case: Between Monetary Policy and Constitutional Conflict' (2016) 23 MJ 17; and on Weiss, among others: Dawson and Bobić (n 15); AAM Mooij, 'The Weiss judgment: The Court's Further Clarification of the ECB's Legal Framework' (2019) 26 MJ 449.

${ }^{28}$ ECB Press Release (n 1). $\quad 29$ ibid. $\quad{ }^{30}$ Decision (EU) 2015/774 (n 2) recital 3.

31 Art 3 Decision (EU) 2020/188 (n 2) sets out eligibility criteria for government bonds that can be purchased under the PSPP. In particular, bonds must be of investment grade.

32 Decision (EU) 2020/188 (n 2) art $6 .{ }_{33}^{33}$ Data from $<$ https://www.ecb.europa.eu/mopo/ implement/omt/html/index.en.html>. 
of monetary policy and credit provision to the economy. ${ }^{34}$ Thus, the programmes ostensibly pursue monetary policy goals. They are qualified by the ECB as non-standard monetary policy measures that are deployed when conventional policy instruments fail to produce their intended effects. ${ }^{35}$ However, there is widespread agreement that the OMT programme contributed critically to containing the Eurozone crisis at its height in 2012, when Mario Draghi made his famous statement that the ECB would 'do whatever it takes to preserve the euro' ${ }^{36}$ followed by a more formal announcement of the OMT programme a few months later. ${ }^{37}$ The announcement as such was sufficient to calm markets and reduce sovereign bond spreads in the Eurozone to levels that did not call into question the ability of individual Member States to refinance their debt. ${ }^{38}$

The legal challenges against OMT and the PSPP were based on similar arguments. The applicants in the main proceedings submitted that the bond purchase programmes exceeded the powers of the ESCB pursuant to Articles 119(2), 127 TFEU and violated the prohibition of monetary financing pursuant to Article 123(1) TFEU. ${ }^{39}$ They exceeded the powers of the ESCB because they had 'a direct impact on the financing sources of ... Member States' 40 and, in the case of OMT, their 'true objective' was 'to "save the euro". ${ }^{41}$ These were economic policy goals that fell within the exclusive remit of the Member States. ${ }^{42}$ Furthermore, the applicants contended that the programmes circumvented the prohibition laid down in Article 123(1) TFEU,

34 Decision (EU) 2015/774 (n 2) recital 2; Decision (EU) 2020/188 (n 2) recital 2. If a change in central bank interest rates alone is insufficient to affect money market rates and, through them, lending and deposit rates and inflation, or policy rates have reached their lower bound, asset purchases can support the transmission of a central bank's monetary policy stance by reducing the risk of future interest rate changes associated with bonds (so-called duration risk) and strengthening the capital position of banks holding sovereign bonds: P Andrade et al., 'The ECB's Asset Purchase Programme: An Early Assessment' (2016) ECB Working Paper No 1956, 3.

35 Conventional policy instruments are open market operations, standing facilities and reserve requirements for credit institutions, Protocol (No 4) on the Statute of the European System of Central Banks and of the European Central Bank arts 18, 19.

36 M Draghi, “"Whatever It Takes” Speech' (Global Investment Conference, London, 26 July 2012). He made similar remarks at the press conference where the OMT decision was announced: $M$ Draghi and V Constâncio, 'Introductory Statement to the Press Conference (with Q\&A)' (ECB, Frankfurt am Main, 6 September 2012) <https://www.ecb.europa.eu/press/pressconf/2012/html/ is 120906.en.html>.

37 ECB Press Release (n 1). For an overview of existing research concerning the EU's response to the Eurozone crisis, see T Sadeh, 'How Did the Euro Area Survive the Crisis?' (2019) 42 West European Politics 201.

${ }^{38}$ C Gerner-Beuerle, E Küçük, and E Schuster, 'Law Meets Economics in the German Federal Constitutional Court: Outright Monetary Transactions on Trial' (2014) 15 German LJ 281, 298301 .

39 Opinion of AG Cruz Villalón in Case C-62/14 Gauweiler and Others EU:C:2015:400, paras 94, 206; Opinion of AG Wathelet in Case C-493/17 Weiss and Others EU:C:2018:1000, para 25.

${ }^{40}$ Gauweiler, Opinion of AG Cruz Villalón (n 39) para 94. Similar concerns were raised in Weiss (n 9) para 16 (third question referred by the German Federal Constitutional Court).

41 Gauweiler, Opinion of AG Cruz Villalón (n 39) para 95.

42 TFEU art 120. 
because purchases under OMT and the PSPP were, in their economic effects and the incentives they created for Member States to adjust their budgetary policies, equivalent to direct purchases of government bonds in the primary market. ${ }^{43}$ The Court of Justice held that OMT and the PSPP complied with the Treaty in all respects. The FCC accepted the Court's assessment of OMT, provided asset purchases were subject to strict limits. ${ }^{44}$ It also concluded that the PSPP did not 'manifestly' circumvent the prohibition of monetary financing. ${ }^{45}$ However, it held that the ECB had exceeded its monetary policy mandate, because it had failed to balance the monetary policy objectives pursued with the PSPP against the economic policy effects of the programme. ${ }^{46} \mathrm{We}$ will deal with these two points - the ECB's monetary policy mandate and the prohibition of monetary financing - in the next two sections.

\section{MONETARY POLICY MANDATE}

The EU has exclusive competence to conduct a single monetary policy for the Member States whose currency is the euro, while economic policy falls within the competence of the Member States. ${ }^{47}$ Pursuant to Articles 119(2), 127 TFEU, the primary objective of the EU's monetary policy is the maintenance of price stability. Other than this reference, the Treaty contains no description of what monetary policy involves. In both Gauweiler and Weiss, the question therefore arose how to delimit the ECB's mandate and distinguish monetary from economic policy. We will discuss first the formula developed by the Court of Justice and then the alternative approach of the FCC, which rejected the Court's interpretation as methodologically untenable.

\section{A. The Direct/Indirect Effects Test of the Court of Justice}

Since Pringle, the Court of Justice has used a two-pronged test to distinguish between monetary and economic policy. It asks, first, whether the ECB pursues an objective that belongs to monetary or economic policy and, second, whether the instrument used to achieve that objective can be qualified as a monetary or an economic policy instrument. ${ }^{48}$ The second part of this test is easy to apply, since the ECB's monetary policy instruments are

43 Gauweiler, Opinion of AG Cruz Villalón (n 39) paras 205-8; Weiss, Opinion of AG Wathelet (n 39) para 54.

44 In its reference in Gauweiler, the FCC held that an asset purchase programme violated the prohibition of monetary financing, unless the volume of the programme was limited, interest rate spreads were not neutralised, purchases did not interfere more than necessary with the process of price formation, in particular because the Eurosystem observed a blackout period before it purchased bonds on the secondary market, bonds were not held until maturity, and the ESCB did not participate in a debt cut, OMT referral (n 7) paras 87-94, 100; FCC judgment on OMT (n 10) paras 190-6. 45 FCC judgment on PSPP (n 11) paras 197-217. 46 ibid paras 167-77.

47 Art 3(1)(c) TEU.

48 Pringle (n 9) para 55; Gauweiler (n 8) para 46; Weiss (n 9) para 53. 
enumerated in the Protocol on the ESCB and the ECB. Open market operations are a widely used type of monetary policy instrument. They are carried out, among other means, by buying and selling marketable instruments in financial markets. ${ }^{49}$ Both OMT and the PSPP fall squarely within this definition. ${ }^{50}$

The first part of the Court's test is more problematic. The purported goals of both OMT and the PSPP are standard monetary policy objectives: repairing the monetary policy transmission mechanism and safeguarding the singleness of monetary policy. ${ }^{51} \mathrm{~A}$ functioning monetary policy transmission mechanism is a precondition for benchmark interest rate decisions to influence inflation and hence the ECB's ability to achieve its primary objective of maintaining price stability. ${ }^{52}$ Furthermore, Article 119(2) TFEU provides that the Eurozone shall have 'a single monetary policy', which is not the case if monetary policy decisions are ineffective in some parts of the Eurozone because of a disruption to the transmission mechanism. This much was not disputed in Gauweiler and Weiss. In response to the submissions of the applicants in the main proceedings, the Court of Justice then added a second step to the analysis that went beyond the stated goals of the measures and inquired into their effects. This second layer of analysis can be seen as an objective corrective to a test that necessarily has to rely on the published rationale behind a measure and, hence, is largely subjective. ${ }^{53}$ The Court held that a measure whose stated aim concerned the promotion of the monetary policy objectives of Articles 119(2) and 127(1) TFEU was not equivalent to an economic policy measure 'for the sole reason that it may have indirect effects that can also be sought in the context of economic policy'. ${ }^{54}$ This test relied on Pringle, where the Court had stated that a financial assistance mechanism that was designed to safeguard financial stability had to be regarded as falling within economic policy and did not become a monetary policy measure for the sole reason that it may have indirect effects on a monetary policy objective such as price stability. ${ }^{55}$ Conversely, in Gauweiler and Weiss, the effect of

\footnotetext{
49 Protocol (No 4) on the Statute of the European System of Central Banks and of the European Central Bank art 18.1.

50 Gauweiler (n 8) para 54; Weiss (n 9) para 69. The selectivity and conditionality of OMT (see the text to nn 28 and 29 above) made no difference in this context. The Court argued that the TFEU and the Protocol on the ESCB and the ECB did not require open market operations to be carried out in all Eurozone Member States, and conditionality simply served to ensure that the ESCB's purchases did not give rise to moral hazard and imperil the economic policies of the Member States, Gauweiler (n 8) paras 55-61.

51 ECB Press Release (n 1); Decision (EU) 2015/774 (n 2) recitals 2-4; Decision (EU) 2020/188 (n 2) recitals 2, 10. See also the text to (nn 28, 30, 34).

52 The monetary policy transmission mechanism will be discussed in more detail presently in the text.

53 In analysing the objectives of OMT and the PSPP, the Court indeed relied exclusively on the press release and the ECB decision setting out the aims of the two programmes, and discussed whether these aims were consistent with the objectives of monetary policy as formulated in arts 119(2) and 127(1) TFEU, Gauweiler (n 8) paras 47-50; Weiss (n 9) paras 54-7.

54 Weiss (n 9) para 61. Similar Gauweiler (n 8) para $52 . \quad{ }_{55}$ Pringle (n 9) para 56.
} 
OMT on financial stability and the impact of the PSPP on refinancing conditions of Eurozone governments were, in the opinion of the Court, examples of indirect economic policy effects. ${ }^{56}$

From the discussion of indirect effects in Gauweiler and Weiss, it is not easy to understand how the Court's test is intended to operate. ${ }^{57}$ Some passages especially in Weiss, which contains the most detailed examination of indirect effects, ${ }^{58}$ seem contradictory. For example, the Court acknowledged that the PSPP was capable of having an impact on the balance sheets of commercial banks that sold government bonds to the Eurosystem and that such an effect might also be sought through economic policy measures. ${ }^{59}$ In the following paragraphs, it then dismissed the argument that this effect called the monetary policy nature of the PSPP into question, because indirect effects had "no consequences for the purposes of classification of the measures at issue'. ${ }^{60}$ Taken literally, the Court's example is perplexing. Asset purchases by the Eurosystem have, by definition, a direct impact on the balance sheets of the sellers (and their refinancing conditions) by replacing one asset (government bonds) with another (cash). On the other hand, the one effect that falls undoubtedly within the area of monetary policy - the impact of asset purchases on price stability - is clearly an indirect effect. The ECB has no direct influence over inflation and instead affects price levels through various economic channels. As the Court of Justice emphasised in both Gauweiler and Weiss, such economic effects are a precondition for the ECB's policy decisions to achieve their ultimate objective. ${ }^{61}$

One possible interpretation of the Court's comments on indirect effects is this: All effects other than those that have an impact on the singleness of European monetary policy and price stability (the monetary policy objectives laid down in Articles 119(2) and 127(1) TFEU) are by definition indirect effects. However, this interpretation would distort the ordinary meaning of 'direct' and 'indirect'. If this is what the Court had meant, it would have been more natural to speak simply of 'effects'. It would also render the effects-based considerations in Gauweiler and Weiss largely redundant. Provided a measure's purported goal belonged to monetary policy and it had some (direct or indirect) effects on monetary policy objectives, it would qualify as a monetary policy measure. Indirect effects on price stability are, however, widespread when economic policy decisions are taken. ${ }^{62}$ A test that did not assess the direct (or

56 Gauweiler (n 8) paras 51-2; Weiss (n 9) paras 63-4.

57 In spite of their importance for a distinction between economic and monetary policy, the Court's considerations of the effects of asset purchases in Gauweiler and Weiss have not received much attention in the literature. An exception is A Steinbach, 'Effect-Based Analysis in the Court's Jurisprudence on the Euro Crisis' (2017) 42 ELRev $254 . \quad 58$ Weiss (n 9) paras 58-67.

59 ibid para 59.

61 Gauweiler (n 8) para 108; Weiss (n 9) paras 64-7.

62 See, eg, K Weyerstrass et al., 'Economic Spillover and Policy Coordination in the Euro Area' (2006) European Economy Economic Paper No 246 (showing that, for example, measures 
alternatively the predominant ${ }^{63}$ ) effects of a measure would make any objective differentiation between monetary and economic policy therefore largely impossible.

More convincing is an alternative interpretation that is based on the ordinary meaning of 'direct' and 'indirect' and distinguishes between monetary and economic policy effects by asking whether an effect is a necessary part of the transmission of a monetary policy decision. This interpretation would lead to a clear demarcation of monetary policy and allow us to make sense of the Court's examples in Weiss. Secondary market asset purchases have an impact on a bank's balance sheet and refinancing conditions. Even though these effects are economic in nature, they do not result in a qualification of asset purchase programmes as economic policy instruments, because they contribute directly to the transmission of monetary policy decisions. Or, to put it differently: the direct effects of such a measure belong to monetary policy because they are part of the monetary policy transmission mechanism. The impact that secondary market asset purchases have on the refinancing conditions of Eurozone governments also do not render the measure an economic policy measure, because these are indirect economic effects.

However, it is questionable whether the direct/indirect effects test, thus understood, can justify the conclusion that both OMT and the PSPP are monetary policy measures. Both purchase programmes were intended to, and did, address disruptions to the monetary policy transmission mechanism, and both had some effects on goals belonging to economic policy. But the similarities end there. In order to investigate the precise effects of the two programmes and their differences, a brief description of the monetary policy transmission mechanism may be useful.

Monetary policy decisions are transmitted to the economy in several steps. Simplifying considerably, a central bank sets the interest rates under its control, in the Eurozone in particular the rates on the main refinancing operations (the rate at which the central bank provides short-term liquidity to financial institutions), the deposit facility (the rate at which banks can make overnight deposits with the Eurosystem), and the marginal lending facility (the rate at which banks can borrow money overnight from the Eurosystem). These rates affect the refinancing costs of financial institutions in the money market and, through them, the rates at which banks lend to, and accept deposits from, their customers. These latter rates, in turn, influence asset prices and saving, consumption, and investment decisions of households and firms. Finally, the behaviour of households and firms affects supply and demand in the markets for goods and services and shifts prices in these markets accordingly.

contributing to fiscal consolidation and structural reform - both clearly outside of the mandate of the ECB - have effects on interest rates and, through them, price levels).

${ }^{63}$ An assessment of the predominant effects of a policy measure is effectively what the FCC suggests through its lens of proportionality, see the discussion in Section III.B. 
At the time of the OMT decision, the Governing Council of the ECB considered the Eurozone to be in a 'bad equilibrium' where concerns about the solvency of some Member States and the continued viability of monetary union had driven up interest rates on government bonds. This made it more costly for Member States to refinance their debts, thus creating the risk that a liquidity crisis would degenerate into a solvency crisis, even if the initial concerns did not (fully) justify the spike in interest rates. ${ }^{64}$ The monetary policy transmission mechanism was disrupted because financial institutions in the affected Member States were effectively excluded from international capital and money markets as the macroeconomic environment deteriorated. ${ }^{65}$ The ECB's intervention was intended to eliminate the risk premia that reflected the threat that a liquidity crisis might develop into a self-fulfilling solvency crisis. ${ }^{66}$ The bank did so by offering to buy potentially unlimited amounts of government bonds from solvent issuers, ${ }^{67}$ thus performing a de facto role of lender of last resort for national governments to resolve liquidity (but not solvency) crises. ${ }^{68}$

In contrast, the PSPP was adopted because the ECB's standard monetary policy tools had been exhausted. At the time of the initial commencement of the purchase programme in March 2015 and when it was restarted in November 2019, the rates on the main refinancing operations and the marginal lending facility were close to or at their zero bound, and the deposit

64 M Draghi, press conference of 6 September 2012 (n 36). For a formal model, see P De Grauwe and Y Ji, 'Self-Fulfilling Crises in the Eurozone: An Empirical Test' (2013) 34 Journal of International Money and Finance 15, 33-5.

65 See, for example, Y Stournaras, 'The Impact of the Greek Sovereign Crisis on the Banking Sector-Challenges to Financial Stability and Policy Responses by the Bank of Greece' (keynote speech at the London Business School Greek Alumni Association and Stanford Club of Greece event 'Breaking the Bottlenecks - Steps towards Sustainable Growth', 8 June 2016) 2 <www.bis. org/review/r160628a.htm>.

66 In the words of Mario Draghi at the press conference of 6 September 2012 (n 36), the ECB sought to 'break' the self-fulfilling expectations of the impending insolvency of Eurozone States and a disintegration of the Eurozone.

67 OMT is conditional on the relevant Member State receiving EFSF/ESM assistance (ECB Press Release (n 1)), and such assistance is only granted when the public debt of the recipient State is sustainable. Pursuant to the ESM Treaty art 13(1)(b), the Commission conducts a debt sustainability analysis together with the IMF before financial assistance is granted. If the debt sustainability analysis reveals that a country could be insolvent, the recipient State is required to negotiate a comprehensive plan with its private creditors to restore debt sustainability, European Commission, European Stability Mechanism (ESM) - Q\&A, MEMO/10/636.

${ }^{68}$ P De Grauwe, Economics of Monetary Union (13th edn, Oxford University Press 2020) 133$5 ; \mathrm{K} \mathrm{Hu}$, 'The Institutional Innovation of the Lender of Last Resort Facility in the Eurozone' (2014) 36 Journal of European Integration 627. While OMT effectively enables the ECB to perform lenderof-last-resort functions for the Member States of the Eurozone, the Maastricht Treaty that established monetary union did not provide for a lender of last resort, and the provisions on monetary union discussed here call into question whether lender-of-last-resort activities of the ECB are covered by the Treaty. See Borger (n 27) 148-52 and 184-5 for an overview of the legal issues. 
facility rate was negative. ${ }^{69}$ Nevertheless, inflation remained significantly below the central bank's target of close to 2 per cent. ${ }^{70}$ The bond purchase programme was initiated because, among other reasons, the ECB was of the view that the adopted monetary policy measures had resulted in a 'lower than expected monetary stimulus' and there was no room to loosen monetary policy further by using traditional tools. ${ }^{71}$ By purchasing government bonds from private institutions in the secondary market, the programme was intended to 'induc[e] financial intermediaries to increase their provision of liquidity to the interbank market and credit to the euro area economy'. ${ }^{72}$

It is clear from this description that OMT and the PSPP are qualitatively very different measures that have different direct and indirect effects. The (intended and actual) direct effect of OMT was the resolution of a liquidity crisis that imperilled the solvency of financial institutions, governments, and more generally financial stability. ${ }^{73}$ It thus had effects comparable to financial assistance granted by the ESM, which the Court held to be a matter of economic policy in Pringle. As a consequence of the resolution of the liquidity crisis and the restoration of an equilibrium in the money market that was not distorted by self-fulfilling expectations (and hence as an indirect effect of OMT), the ECB's intervention ensured that benchmark interest rate decisions would influence the money market and would be transmitted further to the real economy. ${ }^{74}$ The PSPP, on the other hand, operates directly at the second stage of the transmission mechanism by increasing demand for government bonds and hence lowering refinancing costs for financial institutions, which can then be passed on to the institutions' customers. The

69 The key interest rates are published on the website of the ECB <www.ecb.europa.eu/stats> (follow hyperlinks 'ECB/Eurosystem policy and exchange rates' and 'Official interest rates').

70 When the programme was initially announced and when it was restarted, in January 2015 and September 2019 , inflation was $-0.6 \%$ and $0.8 \%$, respectively. Data are from $<$ https://sdw.ecb. europa.eu>.

71 Decision (EU) 2015/774 (n 2) recital 3; Decision (EU) 2020/188 (n 2) recital 6.

72 Decision (EU) 2015/774 (n 2) recital 4.

73 Members of the Executive Board of the ECB acknowledged that the ECB saw the OMT decision as a tool to prevent a breakup of the Eurozone and contribute to a resolution of the sovereign debt crisis, P Praet, 'The ECB and Its Role as Lender of Last Resort during the Crisis' (speech at the Committee on Capital Markets Regulation conference, 'The Lender of Last Resort - an International Perspective', Washington DC, 10 February 2016) <www.ecb.europa.eu/ $\mathrm{press} / \mathrm{key} /$ date/2016>. See in particular fn 2 of the transcript of the speech. For evidence associating the announcement of OMT with a substantial decrease in sovereign bond yields in the Eurozone, see C Altavilla, D Giannone and M Lenza, 'The Financial and Macroeconomic Effects of the OMT Announcements' (2016) 12 International Journal of Central Banking 29; P De Grauwe and Y Ji, 'Correcting for the Eurozone Design Failures: The Role of the ECB' (2015) 37 Journal of European Integration 739; J Jäger and T Grigoriadis, 'The Effectiveness of the ECB's Unconventional Monetary Policy: Comparative Evidence from Crisis and Non-Crisis Euro-Area Countries' (2017) 78 Journal of International Money and Finance 21.

${ }^{74}$ Indeed, AG Cruz Villalón said as much in his opinion in Gauweiler. He explained that unblocking the monetary policy transmission channels was the 'indirect aim' of the OMT programme, and reducing the interest rates required of certain Member States to 'normal levels' its 'immediate objective', Opinion of AG Cruz Villalón (n 39) para 259. 
Court's direct/indirect-effects distinction, therefore, if it is understood as we suggest here, provides a satisfactory explanation for the classification of the PSPP, but not OMT, as a monetary policy measure. ${ }^{75}$

\section{B. The FCC's Proportionality Test}

The German Federal Constitutional Court suggested an alternative type of effects-based test to delimit monetary policy on objective grounds. It held in its judgment in Weiss that a measure that was ostensibly adopted to pursue a monetary policy objective exceeded the ECB's mandate if the economic and social policy effects resulting from the measure, for example its effects on 'public debt, personal savings, pension and retirement schemes, real estate prices and the [preservation] of economically unviable companies', were disproportionate to its monetary policy goals. ${ }^{76}$ The Court of Justice agrees that a bond-buying programme can only be adopted and implemented if it is proportionate. ${ }^{77}$ However, the FCC's proposed proportionality test deviates from that of the Court of Justice in two important respects. First, in Gauweiler and Weiss, the proportionality principle was used to constrain the exercise of an existing power, ${ }^{78}$ whereas it served to distinguish between monetary and economic policy in the FCC's judgment. ${ }^{79}$ A measure that has disproportionate effects on considerations falling within the area of economic policy becomes an economic policy measure, even if it (ostensibly or actually) pursues monetary policy objectives. Second, rather than performing a comprehensive balancing of all economic and monetary policy effects of a monetary policy measure, the Court of Justice simply assesses whether the measure is suitable and necessary to attain its objectives and the risk of losses that asset purchases entail is not disproportionate to the interests promoted by the measure. ${ }^{80}$

A number of arguments could be made against the FCC's proportionality test and in favour of the direct/indirect effects test of the Court of Justice. ${ }^{81}$ First, the

\footnotetext{
75 The outcome in the two cases would, of course, be consistent if the first possible interpretation of the direct/indirect-effects distinction, described in the text to (nn 62-3) above, was adopted. However, as we discuss there, this interpretation is unconvincing.

${ }^{76}$ FCC judgment on PSPP (n 11) para 139.

77 Gauweiler (n 8) para 66; Weiss (n 9) para 71.

78 This is clear from Gauweiler (n 8) para 66 and Weiss (n 9) para 71, stating that 'a bond-buying programme forming part of monetary policy' must comply with the principle of proportionality (emphasis added). $\quad{ }_{79}$ FCC judgment on PSPP (n 11) paras 127, 139-43.

${ }^{80}$ Gauweiler (n 8) paras 66-92; Weiss (n 9) paras 71-100.

81 The approach of the FCC has met with overwhelming criticism by commentators. For a summary of initial reactions, mostly published in blogposts, see A Engel, J Nowag and X Groussot, 'Is This Completely M.A.D.? Three Views on the Ruling of the German FCC on 5th May 2020' (2020) 3 Nordic Journal of European Law 128, 134-9. A more in-depth analysis is offered by the contributions to the special issue of the German Law Journal in vol 21(5) (2020): Special Collection on European Constitutional Pluralism and the PSPP Judgment, and by A Bobić and M Dawson, 'Making Sense of the "Incomprehensible": The PSPP Judgment of the German Federal Constitutional Court' (2020) 57 CMLRev 1953, 1974-82.
} 
FCC relies on proportionality to give substance to the principle of conferral. In the opinion of the FCC, the principle of conferral would be rendered 'meaningless' if the ECB's adherence to its monetary policy mandate could not be reviewed fully in light of the principle of proportionality. ${ }^{82}$ It is true that the three principles enshrined in Article 5 TEU-conferral, subsidiarity and proportionality - cannot be separated with perfect clarity. ${ }^{83}$ Proportionality may require a restrictive interpretation of the scope of an existing competence. ${ }^{84}$ However, the FCC's approach is different. It does not determine the limits of a competence conferred on the Union in an abstract manner but introduces a form of State-dependent definition of the ECB's monetary policy mandate. The scope of the Union's competence in monetary policy matters expands or shrinks depending on the state of the economy and the behaviour of economic actors, for example the savings rate and the preference to hold cash or invest in equity compared with an investment in debt instruments. The approach of the Court of Justice, in contrast, maps on to the distinction in Article 5(1) TEU between the 'limits' of Union competences, which are governed by the principle of conferral, and the 'use' of these competences, which is governed by the principles of subsidiarity and proportionality. ${ }^{85}$

Second, the difference in approach has manifest practical consequences. Any policy decision of the ECB, including a decision belonging to its standard monetary policy tools, for example the setting of a benchmark interest rate, could be challenged on the ground that certain economic effects of the decision had not been considered, or had not been accorded sufficient weight, and would have to be qualified as falling within economic policy if its effects on the real economy were disproportionate. Courts would be required to form a view on questions of a technical and evaluative nature that required special expertise. While it is undisputed, including by the FCC, that the ECB enjoys a margin of appreciation when it assesses the consequences of monetary policy decisions, ${ }^{86}$ the judicial review standard required by the FCC involves

82 FCC judgment on PSPP (n 11) para 123.

83 This is particularly true for subsidiarity and proportionality, see, eg, R Schütze, 'Subsidiarity after Lisbon: Reinforcing the Safeguards of Federalism?' (2009) 68 CLJ 525, 532-3, but it is plausible to argue that the obligation to act proportionately also influences the interpretation of the Union's competences.

${ }^{84}$ HCH Hofmann, GC Rowe and A Türk, Administrative Law and Policy of the European Union (Oxford University Press 2011) 129; T Tridimas, The General Principles of EU Law (2nd edn, Oxford University Press 2006) 176.

${ }^{85}$ See (n 78) above. The view that the principles of conferral and proportionality address two analytically separate (even if not entirely independent) questions is widely shared. The former determines whether the Union can act, and the latter how it should act within its competences. See, for example, C Calliess in C Calliess and M Ruffert (eds), EUV/AEUV (5th edn, CH Beck 2016) art 5 EUV para 5; Tridimas (n 84) 176; S Weatherill, The Internal Market as a Legal Concept (Oxford University Press 2017) 175-6.

86 FCC judgment on PSPP (n 11) para 141. 
a more intensive review than the largely procedural ${ }^{87}$ 'manifest error of assessment' standard of the Court of Justice. ${ }^{88}$ Even if courts generally appreciate the need to afford the ECB discretion, there will be a risk that different perspectives regarding the weighting of the interests at stake will make the outcome of litigation more unpredictable. This, in turn, may cast doubt on the legality of actions that fall within the core area of the ECB's mandate and undermine the legitimacy of its monetary policy in those parts of the Union where people disagree with how the ECB balances conflicting economic interests.

Third, the direct/indirect effects test leads to a clearer dividing line between monetary and economic policy and a more objective approach to delimiting the ECB's monetary policy mandate than the FCC's proportionality test. The FCC envisages a two-step process. The consequences of monetary policy decisions must be 'assessed' and then 'weighed'. 89 Presumably, 'assessing' means quantifying. Any quantification of the effects of a monetary policy decision on an intermediate or ultimate target variable, for example asset purchases on yields, involves complex macroeconomic modelling, which is influenced by the assumptions made and the empirical methods used. It is, therefore, not free from subjective choices. This holds even more so for the weighting of the affected interests and the balancing of economic and monetary policy consequences. There is no framework to standardise the effects on different interests (provided they can be quantified in the first place). It is therefore unclear how, say, the risk of deflation can be balanced against the 'economic and social impact' of rising real estate and stock market prices. ${ }^{90}$ Consequently, it is by no means evident that the FCC's proportionality test reinforces the principle of conferral as much as the FCC seems to think, and indeed more so than the direct/indirect effects test, or in a more principled way.

However, we acknowledge that it is possible rationally to disagree about these points. ${ }^{91}$ In particular, it is important to be conscious of the fact that the Court of Justice applies review standards of different intensity depending on the context. The clearest difference exists between the review of measures of the Union and national measures. In the former case, the Court is generally reluctant to intervene, unless a measure is manifestly inappropriate or the

${ }^{87}$ See M Dawson, A Maricut-Akbik and A Bobić, 'Reconciling Independence and Accountability at the European Central Bank: The False Promise of Proceduralism' (2019) 25 ELJ 75, 88-91.

${ }^{89}$ FCC judgment on PSPP (n 11) para 143.

90 The FCC requires these and other types of economic effects to be considered, see ibid paras $139,170-5$.

91 For a (qualified) defence of the proportionality test as formulated by the FCC in Weiss, see, for example, M Goldmann, 'The European Economic Constitution after the PSPP Judgment: Towards Integrative Liberalism?' (2020) 21 German Law Journal 1058, 1073-5; S Simon and H Rathke, “'Simply Not Comprehensible.” Why?' (2020) 21 German Law Journal 950, 951-3. 
result of a manifest error or misuse of power. ${ }^{92}$ In the latter case, the Court is more demanding and requires a showing that there is no less restrictive alternative. ${ }^{93}$ Further differentiations in the standard of review are a function of the nature of the right or interest invoked by the applicant, the policy area, and the relative expertise of the Court compared with that of the decisionmaking body. ${ }^{94}$ The review standard applied to the ECB is, arguably, at the low-intensity end of a spectrum that has been said to range from very deferential to rigorous. ${ }^{95}$ The FCC's holding in Weiss has to be read primarily as a challenge to these perceived double standards, which, in the absence of other effective checks, leave it largely to the ECB to determine its mandate, ${ }^{96}$ rather than as an attempt to impose a 'German understanding of proportionality'97 on the rest of the EU. ${ }^{98}$

In the spirit of the general line of inquiry pursued in this article, we will therefore only probe the FCC's conclusion that the Court of Justice acted ultra vires from the perspective of whether it is rationally defensible. We will approach the FCC's assertion that the decision in Weiss was methodologically untenable from two angles. We will first examine the FCC's response to the test developed by the Court of Justice to distinguish between monetary and economic policy, and we will then ask whether the FCC applied its precedent in Gauweiler consistently in Weiss.

The FCC argued that the Court of Justice, in ascertaining whether a measure fell within the area of monetary policy:

92 P Craig, EU Administrative Law (3rd edn, Oxford University Press 2018) 644-51; Hofmann, Rowe and Türk (n 84) 129-34; Tridimas (n 84) 142-9, 177-83.

93 Craig (n 92) 670-81; Tridimas (n 84) 138, 209-20.

94 G de Búrca, 'The Principle of Proportionality and Its Application in EC Law' (1993) 13 YEL 105,111 .

95 ibid 111. Low intensity proportionality review is particularly prevalent in cases where EU institutions make discretionary policy choices, Craig (n 92) 644-51.

96 For a similar view, see D Grimm, 'A Long Time Coming' (2020) 21 German Law Journal 944, 948; Simon and Rathke (n 91) 953. It should be emphasised that we only explore what motivated the FCC to challenge the proportionality test of the Court of Justice. We do not dispute that there are good reasons why national legislation that impinges, for example, on the free movement rights under the TFEU should be subject to stricter scrutiny than discretionary policy choices of EU institutions, see Craig (n 92) 652-3, 682-4.

97 Engel, Nowag and Groussot (n 81) 136.

98 The FCC takes issue with the fact that the Court of Justice often performs a relatively detailed assessment of the actual economic effects of a challenged measure when it carries out a proportionality review, whereas neither Gauweiler nor Weiss contain such an assessment, FCC judgment on PSPP (n 11) para 143. The FCC then produces a long list of references to decisions of the Court of Justice to substantiate the claim that the Court's review intensity with respect to actions of the ECB is unusually low, but in doing so combines review standards from different contexts, ibid paras 146-52. For this reason, the direction of some of the initial, often strident, criticism of the FCC's judgment in Weiss, which focused on the court's 'German understanding of proportionality', detracted from the true shortcomings of the decision, see Engel, Nowag and Groussot (n 81) 136 for examples and references. We are grateful to Damian Chalmers for making this point. 
accepts the proclaimed objectives of the ECB as fact without further scrutiny and without regard to foreseeable and/or intended - perhaps even primarily soconsequences of the [measure] in the areas of economic and fiscal policy, the possibility of which the ECB at the very least knowingly accepted; in doing so, the CJEU allows the ESCB to decide autonomously on the scope of the competences conferred upon it by the Member States ... [and declares] asset purchases [as valid] even in cases where the purported monetary policy objective is possibly only invoked to disguise what essentially constitutes an economic and fiscal policy agenda. ${ }^{99}$

This is a reading of the Court's approach that ignores the ordinary meaning of the term 'indirect effects' as used in Gauweiler and Weiss. ${ }^{100}$ It is true that the Court of Justice did not balance the (direct or indirect) economic policy effects of the PSPP against the objectives of the programme at the third stage of the proportionality test, as demanded by the FCC. However, it is not true that the Court of Justice, by not doing so, failed to accord 'foreseeable and/or intended ... consequences of [a measure of the ECB] in the areas of economic and fiscal policy' any relevance. As discussed in the previous section, a reading of Gauweiler and Weiss that gives due weight to the ordinary meaning of 'indirect effects' implies that direct effects (and certainly direct effects that are foreseeable and intended) change the character of a measure as monetary or economic policy. The difference to the FCC's test is simply that the delimitation operates along a different dimension: direct versus indirect effects as opposed to a weighting of the different effects. ${ }^{101}$

The FCC's view seems to stem from its disagreement with the Court's treatment of 'foreseeable consequences'. Criticising Gauweiler, the FCC had submitted in its reference in Weiss that the effects of a measure that purportedly pursued a monetary policy objective could not be regarded as indirect if they were 'foreseeable with certainty' and hence either 'intended or knowingly accepted' by the ECB. ${ }^{102}$ From the FCC's perspective, this is convincing, since the FCC argues in favour of a comprehensive balancing of monetary and economic consequences, but does not automatically regard a measure as impermissible if (direct or indirect) consequences for economic policy exist. ${ }^{103}$ The Court of Justice rejected this wide interpretation, because for the Court, the existence of foreseeable economic policy effects (which, according to the FCC, had to be regarded as direct effects because they were foreseeable and knowingly accepted) would otherwise preclude the ESCB

\footnotetext{
99 FCC judgment on PSPP (n 11) paras 136-7.

100 See the two paragraphs starting with the text to (nn 62-3) in Section III.A.

101 This interpretation of Weiss is, thus, the answer to the question posed by some commentators 'why the CJEU did not seek to analyze whether the monetary policy measures were appropriate given the effects on economic policy', Simon and Rathke (n 91) 954.

102 PSPP referral (n 7) para 119; FCC judgment on PSPP (n 11) para 135.

103 See the description of the FCC's proportionality test in the text to (nn 76-80) above.
} 
from implementing the measure. ${ }^{104}$ From the Court's perspective, a broad interpretation of 'direct effects' would have thus made it impossible for the ESCB to pursue its monetary policy mandate, which required it to act on economic conditions to influence price levels. ${ }^{105}$ The FCC and the Court of Justice are, therefore, talking past each other. The passage of the FCC's judgment rejecting the Court's argument that certain effects (namely, indirect effects) may be disregarded even if they are foreseeable and knowingly accepted (which is the passage we reproduced in parts above ${ }^{106}$ ) quotes selectively one paragraph from the Court's decision in Weiss, where the Court spoke of 'effects', rather than distinguishing between direct and indirect effects. ${ }^{107}$ The FCC then concludes that the Court of Justice disregards the economic policy effects of the PSPP altogether. ${ }^{108}$ However, the quoted paragraph is a continuation of the Court's discussion of indirect effects and applies only to them. ${ }^{109}$ The FCC's central point of criticism is therefore a non sequitur.

Second, neither the direct/indirect effects test nor the Court's limited proportionality review of acts of the ECB are new features of the judgment in Weiss. In Gauweiler, the Court of Justice followed an identical methodology to distinguish between monetary and economic policy. It interpreted the term 'monetary policy' according to the two-pronged test set out in the previous section and, once it had established that OMT was to be qualified as a monetary policy measure, examined the proportionality of the measure. ${ }^{110}$ Furthermore, the Court's lenient standard of review, under which the ECB is afforded broad discretion because of the 'technical nature' of its decision and the 'forecasts and complex assessments' that it involves, ${ }^{111}$ reflects the Court's application of the proportionality principle in similar circumstances. ${ }^{112}$ In its judgment on OMT, the FCC regarded this methodological approach as 'tenable and correspond[ing] to the established case law of the Court of Justice', 113 even though the Court used proportionality 'at the level of the exercise of competences'114 and ignored economic policy considerations in its analysis of the proportionality of OMT. It is difficult to understand why the same approach was qualified as not 'tenable from a methodological perspective' and 'objectively arbitrary' in the FCC's PSPP judgment. ${ }^{115}$ The FCC's judgment is thus methodologically problematic itself and can be

\footnotetext{
104 Weiss (n 9) para 67. $\quad 105$ ibid. $\quad{ }_{106}$ FCC judgment on PSPP (n 11) para 137.

107 Weiss (n 9) para 67. $\quad 108$ FCC judgment on PSPP (n 11) para 138.

109 The Court of Justice rejected the FCC's submission that foreseeable effects could not be qualified as 'indirect' in para 62 of its decision in Weiss. It then gave two reasons why an effect was not 'direct' for the sole reason that it was foreseeable, the first discussed in para 63 and the second in paras 64-7.

110 Gauweiler (n 8) paras 46-65 (delimitation of monetary policy) and 66-92 (proportionality).

111 ibid para 68.

113 FCC judgment on OMT (n 10) para 177.

112 See the references in ( $\mathrm{n} 95)$ above.

115 FCC judgment on PSPP (n 11) paras 118, 119.
} 
challenged for reasons of both using an incorrect premise and being inconsistent with the FCC's own precedent.

\section{PROHIBITION OF MONETARY FINANCING}

Article 123(1) TFEU prohibits the ECB and the national central banks from granting credit facilities to Member States or purchasing debt instruments directly from them on the primary market. The prohibition of monetary financing seeks to ensure that financial markets price government debt accurately and penalise excessive deficits, thus giving Member States an incentive to follow a sound budgetary policy. ${ }^{116}$ The risk that the market price of government debt is distorted, of course, exists not only if the Eurosystem purchases government bonds on the primary market, but also if it does so on the secondary market. It is empirically well documented that the announcement of an asset purchase programme leads to a decline in the yields on government bonds. ${ }^{117}$ Indeed, this is necessary for asset purchase programmes to have an effect on the ultimate target variable or variables, notably inflation. ${ }^{118}$

The literature has identified several transmission channels of secondary market asset purchases to interest rates. ${ }^{119}$ To give just one intuitive example, a government bond purchase programme decreases the supply of the purchased securities in the secondary market and replaces them with short-term, risk-free bank reserves (ie cash). According to macroeconomic theory, an increase in the supply of cash goes hand in hand with a decrease in the interest rate on (or an increase in the price of) alternative essentially risk-free assets. ${ }^{120}$ The reason is that investors have different attitudes towards the interest rate risk associated with assets with longer maturities. As the amount of securities with a higher duration risk decreases, those who are comparatively more willing to bear the relevant risk will decide to invest or remain invested, thus exerting a downward pressure on the risk premium required by the market. ${ }^{121}$ Since an increase of bond prices in the secondary market gives an incentive to invest in the primary market, yields decrease, and governments have lower financing costs.

\footnotetext{
116 Gauweiler (n 8) para 100; Weiss (n 9) para 107.

117 For a discussion of the literature and empirical evidence, see JHE Christensen and S Krogstrup, 'Transmission of Quantitative Easing: The Role of Central Bank Reserves' (2019) 129 Economic Journal 249. $\quad 118$ Gauweiler (n 8) paras 108, 110; Weiss (n 9) para 130.

119 Christensen and Krogstrup (n 117) 249-50; A Krishnamurthy and A Vissing-Jorgensen, 'The Effects of Quantitative Easing on Long-Term Interest Rates: Channels and Implications for Policy' (2011) Brookings Papers on Economic Activity 215, 218-25.

120 See, for example, J Tobin, 'Liquidity Preference as Behavior Towards Risk' (1958) 25 The Review of Economic Studies 65, 67-70.

121 J Gagnon et al., 'The Financial Market Effects of the Federal Reserve's Large-Scale Asset Purchases' (2011) 7 International Journal of Central Banking 3, 7.
} 
Given that primary and secondary market purchases have similar effects, a literal interpretation of Article 123 TFEU that prohibited only primary market interventions would be unconvincing, and the Court of Justice has indeed not adopted such a narrow approach. According to the Court, any intervention in sovereign debt markets by the ECB must come with 'sufficient safeguards' that prevent moral hazard and ensure that Member States do not deviate from a sound budgetary policy. ${ }^{122}$ In its OMT decision, the ECB was well aware of the link between asset purchases that resulted in more favourable financing conditions for Member States and the existence (or the risk) of 'policy mistakes', as Mario Draghi put it in the press conference announcing the OMT decision, which imperilled the sustainability of public finances. ${ }^{123}$ The ECB therefore made outright monetary transactions conditional on the participation of the Member State(s) concerned in an EFSF/ESM macroeconomic adjustment programme or precautionary programme and on full compliance with the conditionality attached to such a programme. ${ }^{124} \mathrm{We}$ will first describe the link between conditionality and the prevention of moral hazard, before we analyse the Court's approach to interpreting Article 123(1) TFEU in greater detail in the following section.

\section{A. The ECB's Approach: Conditionality}

All forms of financial assistance by the ESM (and previously the EFSF) must be subject to strict conditionality, which ranges from a macro-economic adjustment programme if stability support is provided by way of a loan to more specific eligibility criteria. ${ }^{125}$ The precise conditions are agreed between the Commission, ECB, IMF and the recipient Member State and laid down in a memorandum of understanding. ${ }^{126}$ They include fiscal conditions intended to ensure the sustainability of the beneficiary Member State's debt, for example the requirement to achieve a specified primary surplus and adopt clearly defined structural policies to meet agreed fiscal targets. ${ }^{127}$ The fiscal policy choices of beneficiary Member States are, accordingly, constrained. In particular, if the memorandum of understanding imposes numerical limits on budgetary aggregates, such as the primary deficit, it is easy to monitor whether a Member State adheres to a sound budgetary policy. Thus, once conditionality is in place, moral hazard is greatly reduced. This explains why the ECB insisted on conditionality in its OMT decision and the Court of

\footnotetext{
122 Gauweiler (n 8) paras 100-2; Weiss (n 9) para 107.

123 M Draghi, press conference of 6 September 2012 (n 36). See also the arguments of the ECB in Gauweiler, Opinion of AG Cruz Villalón (n 39) para 141. $\quad{ }^{124}$ ECB Press Release (n 1).

125 ESM Treaty arts 12(1), 16(2) (ESM loans), 17(2) (primary market support facility), 18(3) (secondary market support facility). 126 ibid art 13(3).

127 See, for example, the Memorandum of Understanding between the Commission and Greece, August 2015, 6-17.
} 
Justice held in Gauweiler that conditionality 'preclude[d] the possibility of $[\mathrm{OMT}]$... acting as an incentive ... to dispense with fiscal consolidation'. ${ }^{128}$

In a different context, the legality of the ESM, it has been pointed out that conditionality cannot guarantee that a Member State will not act irresponsibly in anticipation of receiving financial assistance. ${ }^{129}$ The availability of financial assistance, the argument goes, may prompt Member States to leave the path of fiscal prudence before a macro-economic adjustment programme commences and any constraints on fiscal policy apply. Whether this is a serious risk depends on the political cost that is involved in surrendering fiscal autonomy, which can be substantial, as the Greek example has shown, and the extent to which decision-makers factor that cost in when they make fiscal policy choices. More importantly, the moral hazard at issue here is different from that created by the ESM. Under the OMT programme, the ECB does not hold out the possibility of a bailout. Rather, the announcement of OMT removed the risk of a self-fulfilling solvency crisis and thus allowed Member States ${ }^{130}$ to finance their expenditure at a lower cost than would otherwise have been possible. Increasing expenditure because of lower financing costs does not threaten a sound budgetary position, provided the increase in expenditure reflects the savings from lower interest payments, and may indeed be the welfare-maximising course of action. Once OMT is implemented and the Eurosystem commences its bond-buying programme, a macro-economic adjustment programme must be in place, thus again containing moral hazard.

Consequently, conditionality plays a key role in ensuring that secondary market purchases do not jeopardise the objective of Article 123(1) TFEU. However, the Court of Justice mentioned conditionality in Gauweiler only in passing towards the end of its judgment, after it discussed other safeguards that feature less prominently in the design of OMT at considerable length. ${ }^{131}$ We turn to these other safeguards and the test developed by the Court of Justice in Gauweiler and Weiss now.

\section{B. The Equivalence/Sufficient Safeguards Test of the Court of Justice}

According to the Court of Justice, secondary market asset purchases are incompatible with the prohibition of monetary financing if they are carried out 'under conditions which would, in practice, mean that [they have] an effect equivalent to that of a direct purchase of government bonds from ... the Member States, thereby undermining the effectiveness of the prohibition in Article 123(1) TFEU'.132 The latter point-not undermining the

\footnotetext{
128 Gauweiler (n 8) para 120.

129 P Craig, 'Pringle: Legal Reasoning, Text, Purpose and Teleology' (2013) 20 MJ 3, 8-9.

130 Especially those who find themselves in a bad equilibrium, see the text to (n 64) above.

131 The discussion of art 123(1) TFEU begins in para 93 of Gauweiler, and conditionality is only mentioned in one paragraph (para 120).

132 Gauweiler (n 8) para 97. Similar Weiss (n 9) para 106.
} 
effectiveness of the prohibition of monetary financing - requires, in the view of the Court, that safeguards are built into ECB interventions in government debt markets that limit the impact of asset purchases on Member State incentives. ${ }^{133}$ This two-pronged test has become the general standard against which the compatibility of an asset purchase programme with Article 123(1) is assessed. We shall examine both prongs in turn.

When the Court speaks of 'equivalent effects', it seems to have a test in mind that examines whether secondary market purchases have identical, rather than merely similar, effects to primary market purchases. The Court has held that secondary market transactions are equivalent to primary market transactions 'if the potential purchasers of government bonds on the primary market knew for certain that the ESCB was going to purchase those bonds within a certain period and under conditions allowing those market operators to act, de facto, as intermediaries for the ESCB'. ${ }^{134}$

Requiring certainty establishes a threshold that will virtually never be met. Even in the unrealistic scenario that the Eurosystem committed to purchasing all bonds of a certain issue that were identifiable (thus, all bonds with the same ISIN), sales would presumably only be made under conditions resembling the transactions of an intermediary if the risk that the market price changed between the purchase and sale by the Eurosystem's counterparty was minimal. For this to be the case, the Eurosystem would need to purchase the bonds immediately after they were issued. OMT passed the test easily, because the ECB and national central banks intended to observe a minimum period before purchasing bonds on the secondary market and refrain from making any prior announcement of either the decision to carry out purchases or their volume. ${ }^{135}$

In contrast, the main features of the PSPP, in particular the monthly volume of purchases, the duration of the programme, and the allocation of asset purchases among the national central banks, are announced in advance. However, the observance of a 'blackout period' before any intervention in the secondary market, the possibility to deviate, within certain parameters, from the monthly purchase guidance, and a 33 per cent cap on purchases of both a particular bond issue and all of the outstanding securities of a government meant, in the opinion of the Court, that private market participants could not foresee with certainty whether the Eurosystem would purchase bonds acquired by them in the primary market. ${ }^{136}$ It is evident that certainty is lacking under these conditions. If we accept the narrow definition of 'equivalent effects' set out in Gauweiler and Weiss, purchasers of government bonds in the primary market cannot be regarded as de facto 
intermediaries for the Eurosystem in either OMT or the PSPP, since they bear the risk of price changes until they actually sell to the Eurosystem.

Irrespective of its limited practical relevance, it is questionable whether this prong of the Court's test performs a useful function. The position of private market participants as 'de facto intermediaries for the ESCB' has little bearing on the incentives of Member States to increase or reduce their borrowing, and hence on the goal of the prohibition of monetary financing. As explained, purchases on the secondary market lead to a general lowering of yields on government bonds. Whether the Eurosystem's secondary market purchases have identical (or similar) effects to transactions on the primary market depends, from the perspective of the borrower, not on the certainty with which an individual purchaser can resell bonds to the Eurosystem, but on the volume of the intervention compared with a hypothetical direct intervention in the primary market.

The second prong of the Court's test concerns the effect of asset purchases on Member State incentives. In Gauweiler and Weiss, the Court identified a number of safeguards that, in the Court's opinion, ensured that the asset purchase programmes did not 'lessen the impetus of the Member States concerned to follow a sound budgetary policy'. ${ }^{137}$ First, purchases were only conducted to the extent necessary for the maintenance of price stability (PSPP) or to unblock the monetary policy transmission mechanism (OMT) and were then expected to cease. ${ }^{138}$ This meant, the Court argued, that Member States could not 'rely on the certainty that the ESCB will at a future point purchase their government bonds on secondary markets' and the purchase programmes could not be used to eliminate spreads in interest rates between Member States irrespective of any fiscal differences. ${ }^{139}$

Both points are, of course, correct, but they are, arguably, irrelevant to the objective of ensuring a sound budgetary policy. Even a temporary purchase of government bonds reduces yields and hence financing costs for Member States. This shifts a government's budget constraint, and, assuming that the government seeks to maximise the provision of public goods subject to its budget constraint, it will spend more. Thus, monetary financing of public expenditure occurs. As the Court acknowledged in Gauweiler and Weiss, this effect is inherent in all public sector asset purchase programmes, which are explicitly permitted by the statute of the ESCB and the ECB. ${ }^{140}$ Whether government finances become less sustainable as a result is a different question that depends on the government's fiscal policy after the end of the stimulus package and not on the 'certainty' that the purchase programme will continue indefinitely or the elimination of spreads between Member States.

\footnotetext{
137 Gauweiler (n 8) para 109.

138 Gauweiler (n 8) para 112; Weiss (n 9) paras 133-4.

139 Gauweiler (n 8) para 113. Similar Weiss (n 9) para 132.

140 See (nn 49-50, 118) above and accompanying text.
} 
It is easy to see that this is the case by considering a government's intertemporal budget constraint, which models the government's debt dynamics (change in debt) as a function of expenditure, tax revenue and interest payments. Over the duration of an asset purchase programme, the budget deficit remains constant (change in debt is zero) if an increase in expenditure can be financed out of cheaper debt (lower interest payments). ${ }^{141}$ After a central bank's intervention has ended, the budget deficit, of course, only remains constant if expenditure is again reduced. Without any safeguards, it is perhaps unrealistic to expect that this will happen, given the particularities of the political economy of debt. ${ }^{142}$ However, the structure of an asset purchase programme has nothing to do with this problem. Rather, the necessary safeguards must be in the form of fiscal rules or other controls over fiscal policy. ${ }^{143}$

Second, the ECB's asset purchase programmes were limited in size. ${ }^{144}$ Central banks typically announce the amount of sovereign debt they intend to purchase in a quantitative easing programme each month in advance in order to condition the market. The ECB's PSPP decision is no exception. ${ }^{145}$ Furthermore, asset purchases under the PSPP are allocated among the euro area national central banks according to a predetermined ratio, based on the key for subscriptions to the ECB's capital (rather than the level of debt of a Member State). ${ }^{146}$ The Court of Justice argued that Member States, consequently, had no incentive to increase government debt in response to the implementation of the PSPP, which would only result in a comparatively smaller proportion of a State's bonds being purchased by the Eurosystem. ${ }^{147}$ The OMT programme, in contrast, operates with no ex ante quantitative limits. However, the Court held that OMT was de facto limited in size, since bonds were only eligible for purchase if the issuing Member State underwent a structural adjustment programme, and the Eurosystem was able to sell the purchased bonds at any time. ${ }^{148}$

Again, it is not clear why these aspects of the bank's asset purchase programmes should be relevant to the question of how moral hazard can be contained. The size of OMT is only limited at the level of the Eurozone as a whole, but not at the level of an individual State. ${ }^{149}$ Limitations that exist at the level of an individual State, as under the PSPP, limit asset price distortions, but do not ensure that the Member State concerned will follow a sound budgetary policy. As explained, any meaningful secondary market

${ }^{141}$ For a more formal model, see W Carlin and D Soskice, Macroeconomics: Institutions, Instability and the Financial System (Oxford University Press 2015) 518-19.

${ }_{142}$ On this point, see ibid 535-7.

144 Gauweiler (n 8) para 116; Weiss (n 9) paras 139-41.

145 See, initially, Decision (EU) 2015/774 (n 2) recital 7.

147 Weiss (n 9) para 140. 143 ibid 537-41.

149 Apart from the fact that the ECB declared that it would focus on bonds with shorter maturities, ECB Press Release (n 1). 
intervention will, by definition, have an impact on government bond yields and hence provide an incentive to increase government expenditure. Moral hazard that arises as a consequence of an asset purchase programme can be controlled through appropriate fiscal rules, but not through volume limits on asset purchases or by allocating purchases within the Eurosystem according to a key that is independent of debt levels. Likewise, the resale of bonds by the Eurosystem in the secondary market does not change the fact that the initial purchase may contribute to the financing of government expenditure. This may create commitments on the part of the Member State that cannot be reversed easily when the Eurosystem's intervention ends and hence may initiate an upward trend in the government's debt ratio. Whether the knowledge that the Eurosystem is able to sell purchased bonds constitutes an effective deterrent that prevents the beneficiary Member State from undertaking such commitments in the first place may be doubted.

Third, asset purchases were restricted to bonds that were either of investment grade ${ }^{150}$ or issued by a country subject to a financial assistance programme, notably an EFSF/ESM adjustment programme. ${ }^{151} \mathrm{We}$ have argued above that a structural adjustment programme is an appropriate measure to safeguard against a circumvention of Article 123(1) TFEU, since it establishes fiscal rules and imposes other fiscal constraints on a Member State with the goal of safeguarding or restoring the sustainability of the Member State's public debt. ${ }^{152}$ Whether the risk that a credit rating agency downgrades government debt to below investment grade is sufficient to incentivise a Member State to follow a sound budgetary policy is more difficult to assess. Credit rating agencies will rate an issuer as investment grade only if the issuer has the capacity to meet its financial commitments and respond adequately to adverse economic shocks. ${ }^{153}$ A fiscal policy that seeks to deliver sustainable public finances and allows the government to respond effectively to economic shocks may be called 'sound' within the meaning of Gauweiler and Weiss. In principle, distinguishing between investment grade and non-investment grade securities is, therefore, an appropriate criterion that promotes the objective of Article 123(1) TFEU.

Two objections may be made to this preliminary conclusion. First, credit ratings are a function of the combined consideration of a variety of institutional, economic, fiscal and monetary variables. ${ }^{154}$ The effect of changes along one dimension-in the present context fiscal conditions-on the rating outcome is, therefore, attenuated and possibly offset by changes along other dimensions. In theory, this does not call into question the

\footnotetext{
${ }^{150}$ Decision (EU) 2020/188 (n 2) art 3(2). The Decision requires Credit Quality Step 3 in the Eurosystem's harmonised rating scale, which is equivalent to investment grade, see ECB Monthly Bulletin April 2014, 30. $\quad 151$ Gauweiler (n 8) para 120; Weiss (n 9) para 142.

152 Text to (nn 125-30).

153 See, for example, S\&P Global Ratings Definitions (2017) 5; S\&P Sovereign Rating Methodology (2017) 3.

154 S\&P Sovereign Rating Methodology (2017) 2-5.
} 
suitability of credit ratings to assess the effect that fiscal policy adjustments have on a country's public debt sustainability and resilience to economic shocks. This is evident for variables that have a direct impact on debt levels and debt sustainability, for example the ratio of government debt to GDP or economic growth. ${ }^{155}$ It is reasonable to assume that an asset purchase programme does not change a government's incentives with regard to fiscal policy if an increase in the debt-to-GDP ratio is offset by a more positive assessment of an issuer's economy and growth prospects. The increase in the debt-to-GDP ratio might have been triggered by the asset purchase programme or the improved growth forecast (or both), but the position of the country has not changed in comparison with a scenario where the government had not borrowed more, but the economy had also not improved.

The same line of reasoning holds for 'softer' variables, for example the accountability of government institutions and the absence of corruption. ${ }^{156}$ Again, if an increase in borrowing is offset by an improvement in the institutional environment, it is justified to regard an asset purchase programme as not jeopardising the aim of Article 123(1) TFEU, since better institutions make it more likely that the government will manage its debt more competently and prudently. However, the problem with such 'softer' measures, and more generally with the drawing up of a matrix of variables and their interactions to determine a country's credit rating, ${ }^{157}$ is that they introduce a considerable amount of noise. Inevitably, a certain degree of subjectivity is involved in defining and weighting the relevant variables and assessing a country's situation. Thus, it is possible that a country's creditworthiness deteriorates as a consequence of a monetary policy measure, without this being reflected in a corresponding decrease in the country's credit rating.

The second objection is that credit ratings operate retroactively. It is therefore questionable whether the threat of a potential downgrade is enough to incentivise a Member State not to deviate from a sound budgetary policy when presented with a monetary policy intervention that creates favourable financing conditions. As discussed, credit ratings are partially subjective. Therefore, a downgrade cannot be predicted with certainty and its deterrent effect must be discounted accordingly. Furthermore, those who make fiscal policy decision may rationally decide to accept the risk that the government's credit rating could be downgraded in order to be able to pursue economic policy goals that are regarded as taking priority over fiscal reticence.

While the risk of a credit rating downgrade will, therefore, not always be effective, it is important to note that the investment-grade requirement does not operate in a legal vacuum. We have argued above that some control over

\footnotetext{
155 For an example of the methodology that credit rating agencies typically use to assess a sovereign borrower's economic situation, see ibid 9-12.

156 Such institutional variables are discussed and defined ibid on 5-9. $\quad 157$ See ibid 4.
} 
a Member State's fiscal policy decisions after the termination of an asset purchase programme is essential to prevent the goal of Article 123(1) TFEU from being compromised. Such a control mechanism exists in the EU in the form of the Stability and Growth Pact (SGP) and the Fiscal Compact. ${ }^{158}$ The SGP has introduced a process of budgetary surveillance and coordinated formulation of the Member States' annual budgets and economic policies. ${ }^{159}$ As part of this process, Member States are required to set a medium-term objective for their budgetary position that should be close to balance. ${ }^{160}$ For signatories of the Fiscal Compact, the structural deficit is limited to 0.5 per cent of GDP, unless debt is significantly below 60 per cent of GDP. ${ }^{161}$ Member States that are at their medium-term objective must ensure that government expenditure does not grow more than predicted GDP growth, and Member States that are below their medium-term objective must formulate an adjustment path that includes a rate of expenditure growth below predicted GDP growth. ${ }^{162}$

The Council and Commission monitor compliance with the SGP and issue warnings, recommend policy changes, and, as a last resort, impose sanctions on Member States. ${ }^{163}$ In addition, the SGP contains a corrective arm, also known as the excessive deficit procedure, which is triggered if a Member State exceeds a structural deficit of 3 per cent of GDP or a government-debt-to-GDP ratio of 60 per cent. ${ }^{164}$ The Commission and Council will then recommend adjustments to correct the fiscal imbalances and, if the Member State concerned does not take effective action, step up the excessive deficit procedure, potentially leading to the imposition of fines. ${ }^{165}$

After the SGP was initially criticised for a lack of enforcement, the excessive deficit procedure has been made more automatic and surveillance and

158 The SGP is composed of several measures of primary and secondary EU law: arts 121, 126, 136 TFEU, Protocol (No 12) on the Excessive Deficit Procedure annexed to the TFEU [2008] OJ C115/279, and the 'Six-pack' and 'Two-pack' packages of regulations and directives. For a full list, see <https://ec.europa.eu/info/business-economy-euro_en> (follow hyperlinks 'EU Economic governance: monitoring, prevention, correction' and 'Legal basis of the Stability and Growth Pact'). The European Fiscal Compact refers to art 3 Treaty on Stability, Coordination and Governance (TSCG), which requires the signatory States to maintain a balanced budget.

159 For a description of the process, see European Commission, 'Vade Mecum on the Stability and Growth Pact' (European Economy Institutional Paper 101, April 2019) 74-86.

160 Art 2a Council Regulation (EC) 1466/97 on the strengthening of the surveillance of budgetary positions and the surveillance and coordination of economic policies [1997] OJ L209/1, as amended by Council Regulation (EC) No 1055/2005 [2005] OJ L174/1, and Regulation (EU) No 1175/2011 [2011] OJ L306/12, requires Member States to specify a medium-term budgetary objective within a range of $-1 \%$ of GDP and surplus.

161 Art 3 TSCG.

162 Art 5(1) Council Regulation (EC) 1466/97. See also European Commission (n 159) 7-32 for the methodology underpinning the calculation of the medium-term budgetary objective and the determination of an appropriate adjustment path.

163 Art 121(4) TFEU; Regulation (EU) No 1173/2011 on the effective enforcement of budgetary surveillance in the euro area [2011] OJ L306/1.

164 Art 1 Protocol (No 12) on the Excessive Deficit Procedure. 165 Art 126 TFEU. 
coordination have been strengthened with the adoption of the so-called 'Sixpack'. ${ }^{166}$ Recent empirical findings indicate that the SGP now significantly shapes fiscal policy in the Eurozone and gives an impetus for fiscal consolidation. ${ }^{167}$ It does not seem incoherent to argue, as did the Court of Justice in Weiss, that the threat posed by a potential credit rating downgrade, in an environment where fiscal policy choices of Member States are already constrained, provides a sufficient safeguard against the moral hazard otherwise caused by an asset purchase programme.

\section{THE PANDEMIC EMERGENCY PURCHASE PROGRAMME AND OTHER GOVERNMENT BOND MARKET INTERVENTIONS}

\section{A. Monetary Policy Mandate}

The PEPP aims to counteract 'the serious risks to price stability, the monetary policy transmission mechanism and the economic outlook in the euro area' caused by the COVID-19 crisis. ${ }^{168}$ Under the PEPP, the Eurosystem purchases eligible securities, including bonds issued by Member State governments, on secondary markets. The allocation of purchases is, in principle, based on the key for subscriptions to the ECB's capital, but the Executive Board may decide to deviate from the capital key. ${ }^{169}$ Unlike the PSPP, the PEPP decision does not impose quantitative limits on purchases on an issuer basis. ${ }^{170}$ It also decision does not impose any conditionality on asset purchases, other than that government bonds must be of investment grade, ${ }^{171}$ and furthermore waives this latter requirement for debt securities issued by Greece. ${ }^{172}$

The PEPP falls within the mandate of the ECB if it pursues a monetary policy goal, makes use of a monetary policy instrument, has only indirect effects on policy goals not related to monetary policy, in particular on economic policy

\footnotetext{
166 See (n 158) above for references to the Six-pack. Importantly, sanctions recommended by the Commission under the excessive deficit procedure are now considered adopted unless the Council decides by a qualified majority to reject the Commission's recommendation (reverse qualified majority voting pursuant to arts 4-6 Regulation (EU) No 1173/2011).

167 F Heinemann, M-D Moessinger and M Yeter, 'Do Fiscal Rules Constrain Fiscal Policy? A Meta-Regression-Analysis' (2018) 51 European Journal of Political Economy 69 (finding a constraining effect of budget rules on fiscal aggregates, but also a publication bias that calls the statistical significance of the findings into question); J De Jong and N Gilbert, 'Fiscal Discipline in EMU? Testing the Effectiveness of the Excessive Deficit Procedure' (2020) 61 European Journal of Political Economy 101822 (finding that EDP recommendations have led to additional fiscal consolidation). $\quad{ }^{168}$ Decision (EU) 2020/440 (n 3) recital $4 . \quad{ }^{169}$ ibid recital 5, art 5.

170 Art 4 of Decision (EU) 2020/440 provides that '[p] urchases shall be carried out under the PEPP to the extent deemed necessary and proportionate to counter the threats posed by the extraordinary economic and market conditions on the ability of the Eurosystem to fulfil its mandate'. In contrast, purchases under the PEPP are limited to 33 per cent per ISIN and 33 per cent of the outstanding securities of an issuer, Decision (EU) 2020/188 (n 2) art 5. For a comparison of the PEPP with the PSPP, see also Bobic and Dawson (n 81) 1956-7.

${ }_{171}$ Decision (EU) 2020/440 (n 3) art 1(2)(a). $\quad 172$ ibid art 3.
} 
goals (we have called this condition the Court's direct/indirect effects test), and is proportionate to the goal pursued. It is clear that the first two conditions are satisfied. Asset purchases in secondary markets constitute a monetary policy instrument, and the goals pursued by the PEPP according to the ECB decision establishing the purchase programme fall within monetary policy.

The application of the direct/indirect effects test is more difficult. As currently implemented, purchases under the PEPP are largely in line with the ECB capital key and mirror transactions under the PSPP. Like the PSPP, the PEPP thus has an impact at the second stage of the monetary policy transmission mechanism, and any effects that fall within economic policy, for example on refinancing costs of Member States and general economic conditions, are indirect. ${ }^{173}$ However, the financial firepower of the PEPP could also be concentrated on individual Member States. This would directly affect financial stability if the purchases (or their announcement) removed the threat of a self-fulfilling solvency crisis by guaranteeing the liquidity of a Member State (that is, the ECB operated through the PEPP as a lender of last resort). Thus, where a Member State experiences a liquidity crisis, the PEPP could be used to the same effect as OMT. It is unlikely that asset purchases under the PEPP will indeed be deployed in this way, since the credit rating of a Member State that experiences difficulties in refinancing its debt is likely to be downgraded to below investment grade. This would render government bonds-with the exception of Greek bonds-ineligible, unless the PEPP decision was amended to include another waiver. Nevertheless, it is important to note that a consistent application of the direct/indirect effects test imposes limitations on how the PEPP, and more generally a programme that allows for selective asset purchases, can be used. ${ }^{174} \mathrm{~A}$ bond buying programme that has a direct effect on financial stability or other economic policy goals is illegal, and there is no need to take recourse to the proportionality test of the Court of Justice, or the FCC's more comprehensive proportionality review, to achieve this result.

The Court's proportionality test constitutes an additional constraint on the discretion of the ECB that is relevant to the question whether the programme's monetary policy goal could have been achieved through other means, for example the use of standard monetary policy tools, a purchase programme with a smaller envelope, or a programme that targeted a narrower range of eligible assets. ${ }^{175}$ In addition, the risks associated with asset purchases, notably the exposure of national central banks and the ECB to the risk of losses, must not be manifestly disproportionate to the PEPP's objectives. ${ }^{176}$

\footnotetext{
173 See the analogous arguments in the text to (nn 73-5).

174 It is worth emphasising that selectivity alone does not mean that asset purchases have economic policy effects. An asset purchase programme has effects on financial stability, and thus on an economic policy goal, if selectivity is used to signal the availability of sufficient liquidity to prevent a liquidity crisis from developing into a solvency crisis.

175 Necessity stage of the proportionality review, see, eg, Weiss (n 9) paras 79-92.

176 Balancing stage of the proportionality review, see, eg, Weiss (n 9) paras 93-9.
} 
As mentioned, the PEPP allows for greater flexibility than the PSPP and entails, arguably, a greater risk of losses, since not all purchased bonds are of investment grade. However, the PSPP currently operates on the basis of the same key for the allocation of asset purchases and the same loss sharing principles as the PSPP. National central banks purchase securities of issuers based in their jurisdiction, and the potential mutualisation of losses is limited to the securities purchased by the ECB. ${ }^{177}$ Given these features of the PEPP and the wide margin of discretion that the ECB enjoys in deciding how to implement monetary policy, which is reflected in the 'manifest error of assessment' standard that the Court of Justice employs in its proportionality review, ${ }^{178}$ it is therefore likely that the Court will hold that the PEPP is proportionate.

The FCC's criticism of the standard of review of the Court of Justice concerned the fact that the Court only balanced the monetary policy objectives of asset purchases against the risk of losses and not more generally against the 'adverse effects' of asset purchases, for example the effect that low interest rates have on household savings. ${ }^{179}$ In the view of the FCC, this rendered the Court's proportionality review 'meaningless'. ${ }^{180}$ The discussion in the preceding paragraphs and in Section III.B demonstrates that this criticism is misplaced. The function of distinguishing between monetary and economic policy measures, and thus protecting the Member States against encroachment on their competences, is performed by the direct/indirect effects test, not the proportionality test. ${ }^{181}$ The Court's proportionality test, on the other hand, has the function of assessing whether the actual monetary policy effects of a measure map on to the purported monetary policy goals of that measure. For example, if the selective purchase of government bonds was justified with the disruption of the monetary policy transmission mechanism in some parts of the Eurozone but not in others, but there was insufficient evidence that that was actually the case, a purchase programme that targeted individual Member States would be disproportionate. In contrast to the FCC's approach, the legal tests developed by the Court of Justice lead to a conceptually clear distinction between the principles laid down in Article 5 TEU. ${ }^{182}$ The direct/indirect effects test polices the principle of conferral and the proportionality test the exercise of a conferred power.

\footnotetext{
177 The ECB's share of purchases amounts to 20 per cent of total public sector asset purchases, see Pandemic emergency purchase programme (PEPP) Questions \& Answers, Q7 <www.ecb. europa.eu/mopo/implement/pepp/html/pepp-qa.en.html>. $\quad{ }_{178}$ Weiss (n 9) paras 78, 91.

179 FCC judgment on PSPP (n 11) para 133. 180 ibid.

181 According to the FCC, its more comprehensive proportionality review has the purpose of safeguarding the competences of the Member States and reinforcing the principle of conferral, see ibid paras $133-4$ and the text to (n 82).

182 See the text to (n 82).
} 


\section{B. Prohibition of Monetary Financing}

The PEPP complies with the prohibition of monetary financing if it does not have effects equivalent to the direct purchase of government bonds on the primary market and provides for safeguards to ensure that Member States have sufficient incentives to follow a sound budgetary policy (equivalence/ sufficient safeguards test). The first part of this test requires that secondary market purchasers do not act as de facto intermediaries for the Eurosystem. This is the case if they cannot foresee with certainty that the Eurosystem will purchase bonds acquired by them in the primary market. ${ }^{183}$ As mentioned, the Court of Justice relies on a multiplicity of criteria to assess foreseeability, including discretion in the timing of purchases and their allocation among national central banks, the duration of the programme, and the existence of a percentage cap on purchases of a particular issuer and bond issue. ${ }^{184}$ Under the PEPP, the Eurosystem follows a 'flexible approach to the composition of purchases', ${ }^{185}$ and, similar to the PSPP, it can be assumed that the Eurosystem will not intervene immediately after a bond issue. ${ }^{186}$ Under these conditions, it is clear that the high threshold of certainty is not met.

Likewise, whether sufficient safeguards exist depends on a consideration of a totality of the circumstances. In Gauweiler and Weiss, the Court highlighted several factors that were important. Purchases were only carried out to the extent necessary to achieve the goals of the programmes, the overall size of the programmes was (de facto) limited, the Eurosystem had the option to sell the purchased bonds at any time, and purchased bonds had to be of investment grade (or, in Gauweiler, purchases were conditional on full compliance with a structural adjustment programme). The decision establishing the PEPP replicates the first three criteria, ${ }^{187}$ but allows the purchase of government bonds of one Member State, Greece, even if the bonds are below investment grade. ${ }^{188}$ However, safeguards exist that allow the continued monitoring of the fiscal policy of the Greek government and the implementation of prior commitments to structural reform. ${ }^{189}$ While this so-called enhanced surveillance framework ${ }^{190}$ imposes less rigid constraints on a Member State's fiscal autonomy than a macro-economic adjustment programme, ${ }^{191}$ it grants the ECB, Commission and Council enhanced powers

183 Text to (n 136) above.

184 Section IV.B.

185 Decision (EU) 2020/440 (n 3) recital 5. Art 5 contains further details.

186 AAM Mooij, 'The Legality of the European Central Bank's Pandemic Emergency Purchase Programme' (2020) BRIDGE Network - Working Paper 5, 12 <https://ssrn.com/ abstract=3677152>. $\quad{ }^{187}$ Decision (EU) 2020/440 (n 3) arts 1 and $4 . \quad 188$ ibid art 3.

189 ibid recital 7. For a report on the nature of these commitments and their implementation, see European Commission, 'Enhanced Surveillance Report - Greece' (European Economy Institutional Paper 127, May 2020).

190 The enhanced surveillance framework is laid down in Regulation (EU) No 472/2013 on the strengthening of economic and budgetary surveillance of Member States in the euro area experiencing or threatened with serious difficulties with respect to their financial stability [2013] OJ L140/1, art 3.

191 See the text to (nn 125-7) above. 
in comparison with those under the SGP to review developments in the Member State concerned and recommend precautionary corrective measures or require the preparation of a draft macro-economic adjustment programme. ${ }^{192}$ Considering that the ECB can, therefore, monitor in a targeted manner how government bond market interventions affect fiscal policy choices and that this is just one of several safeguards built into the PEPP, there are good reasons to conclude that the PEPP will pass the Court's equivalence/sufficient safeguards test. ${ }^{193}$

The FCC was highly critical of the flexible multi-factor test of the Court of Justice in Weiss, although it ultimately held that a 'manifest violation' of Article 123(1) TFEU had not been shown. ${ }^{194}$ Importantly, it emphasised in its judgment that two conditions were indispensable for a public sector asset purchase programme to be legal: a purchase limit of 33 per cent per ISIN and issuer and the requirement that purchased securities were of investment grade. ${ }^{195}$ The PEPP does not fulfil either of these conditions. Thus, if the FCC applies its own criteria consistently, it will conclude that the PEPP constitutes prohibited monetary financing. ${ }^{196}$ However, as discussed in Section IV.B, purchase limits and other criteria that determine whether primary market purchasers act as de facto intermediaries for the Eurosystem do not have a bearing on the question whether Member States have sufficient incentives to follow a sound budgetary policy. Both the FCC and the Court of Justice agree that safeguarding sound public finances is the objective of Article 123(1) TFEU. Under a coherent interpretation of the provision, both courts should, accordingly, come to the conclusion that a purchase limit of 33 per cent is not a necessary condition for compliance with the prohibition of monetary financing.

More generally, a coherent interpretation of Article 123(1) TFEU implies that public sector asset purchase programmes do not constitute prohibited monetary financing if controls over fiscal policy are in place that ensure that a Member

192 Regulation (EU) No 472/2013 arts 3, 14.

193 Most commentators come to similar conclusions, see M Goldmann, 'Borrowing Time. The ECB's Pandemic Emergency Purchase Programme’ (VerfBlog, 27 March 2020) <https://doi.org/10. 17176/20200328-002904-0>; Mooij (n 186); Viterbo (n 196) 675-8, 680-1. M Dawson and A Bobic, 'COVID-19 and the European Central Bank: The Legal Foundations of EMU as the Next Victim?' (Verfblog, 27 March 2020) <https://doi.org/10.17176/20200327-122939-0>, on the other hand, express doubts about the legality of the PEPP. They argue that, because of the PEPP's volume, there was a high probability that bonds would be purchased by the Eurosystem, and the PEPP did not contain any reference to conditionality. However, the equivalence/sufficient safeguards test of the Court of Justice requires certainty, not a high probability. In addition, the necessary safeguards may, but do not have to, stem from conditionality under an assistance programme.

${ }^{194}$ FCC judgment on PSPP (n 11) para 180. The FCC argued that ' $[\mathrm{t}]$ he CJEU's conclusion ... that the PSPP does not violate Art. 123(1) TFEU [met] with considerable concerns'.

195 ibid paras 202, 208.

196 This is also the view of Bobić and Dawson (n 81) 1991-2; A Viterbo, 'The PSPP Judgment of the German Federal Constitutional Court: Throwing Sand in the Wheels of the European Central Bank' (2020) 5 European Papers 671, 681-3. 
State maintains sound public finances while the monetary policy intervention continues and, importantly, also when it ends. ${ }^{197}$ Such controls can be in the form of, for example, ESM conditionality, the requirement that purchased bonds are of investment grade, or enhanced surveillance of issuers if bonds are below investment grade. On the other hand, it is irrelevant for the prohibition of monetary financing whether percentage limits per issuer and ISIN exist, or whether it can be foreseen when the Eurosystem will purchase bonds, what the monthly purchase volume is, how asset purchases are allocated, and for how long the programme will continue.

\section{CONCLUSION: PROSPECTS FOR CONSISTENCY AND COHERENCE IN ADJUDICATING}

\section{UNCONVENTIONAL MONETARY POLICY}

A perception that the legal framework governing European monetary union is applied inconsistently and incoherently threatens the long-term legitimacy of both the Court of Justice and the monetary policy of the ECB. In the jurisprudence of the Court of Justice, inconsistency is a function of the different treatment of measures that had the same direct effect in Pringle and Gauweiler, namely, to safeguard financial stability, and analogously the identical treatment of measures that had different direct effects in Gauweiler and Weiss. This result follows from an application of the Court's own legal test to distinguish between economic and monetary policy. An interpretation of the test based on an ordinary meaning of the criteria developed by the Court, the direct and indirect effects of a measure, implies that Gauweiler was decided incorrectly. It is thus ironic that Gauweiler was ultimately accepted by the FCC, albeit with reservations, ${ }^{198}$ whereas the FCC decided to challenge the supremacy of EU Law in Weiss, a decision that is entirely defensible from the standpoint of consistency and coherence and that is hardly methodologically untenable, as the FCC alleged. It can be assumed that the FCC's uncompromising position in Weiss was influenced at least in part by the ambivalence that the Court of Justice itself injected into its legal analysis by applying its direct/indirect effects test inconsistently. ${ }^{199}$

From an economic point of view, the Court of Justice, of course, had good reasons to decide Gauweiler as it did, given the exceptional circumstances that

197 See the text to (nn 141-3).

198 FCC judgment on OMT (n 10) paras 181-9.

199 Similarly, in the literature, it has been argued that the FCC's decision to declare Weiss ultra vires was as much a reaction to the refusal of the Court of Justice to accept the FCC's arguments in Gauweiler, as it was to the perceived failure to conduct a thorough proportionality review in Weiss, see FC Mayer, 'To Boldly Go Where No Court Has Gone Before: The German Federal Constitutional Court's ultra vires Decision of May 5, 2020' (2020) 21 German Law Journal 1116, 1125; N Petersen, 'Karlsruhe's Lochner Moment? A Rational Choice Perspective on the German Federal Constitutional Court's Relationship to the CJEU After the PSPP Decision' (2020) 21 German Law Journal 995, 1003. In its judgment in Weiss, the FCC indeed criticised the Court of Justice for rendering some of the criteria from its references in Gauweiler and Weiss 'practically meaningless', FCC judgment on PSPP (n 11) para 197. 
existed when the ECB issued its OMT decision. ${ }^{200}$ However, prioritising economic considerations comes at the cost of imperilling the legitimacy of the Court, particularly if it leads to inconsistency in the Court's case law. It is, therefore, perhaps time for the Court to recalibrate its approach and ensure that a consistent and coherent application of the legal tests developed in Pringle, Gauweiler and Weiss is beyond doubt. The Court will have an opportunity to do so in the PEPP litigation. It should underline that the direct/indirect effects test sets objective limits on how the PEPP, and generally public sector asset purchase programmes, can be used and identify these limits more clearly than in Weiss. It should also stress that a coherent interpretation of the prohibition of monetary financing requires the existence of effective controls over the Member States' fiscal policies but does not require asset purchases to be structured so that primary market purchasers cannot expect the bonds they hold to be bought by the Eurosystem.

Such a step would, arguably, alleviate the risk of further conflicts with the FCC. The Court's direct/indirect effects test imposes an effective constraint on the ability of the ECB to determine the scope of its mandate autonomously. ${ }^{201}$ It thus introduces an important element of democratic accountability into the legal framework governing monetary policy measures $^{202}$ and addresses the main point of criticism of the FCC. It is also superior to the alternative test proposed by the FCC, which consists in a proportionality review that requires a balancing of the economic and monetary policy effects of monetary policy decisions. ${ }^{203}$ Reinforcing the role that the direct/indirect effects test plays in monitoring the principle of conferral might make it easier for the FCC to accept that the structural features of public sector asset purchase programmes that it held out as necessary conditions for compliance with the prohibition of monetary financing (some of which are absent in the case of the PEPP) should not, in fact, be seen as preconditions. For the long-term success of a rules-based monetary union, it is to be hoped that both the Court of Justice and the FCC will take steps in the indicated directions.

200 See (n 73) and accompanying text.

202 de Haan and Eijffinger (n 18) 397-8.
201 See Section III.

203 See the text to (nn 76-82). 